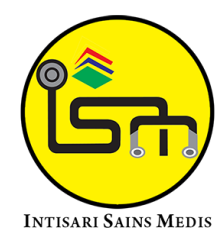

Published by Intisari Sains Medis

\section{Efek ekstrak sambiloto (Andrographis paniculata) terhadap ekspresi vascular cell adhesion molecule-1 (VCAM-1) dan intimal media thickness (IMT) pada mencit yang terpapar asap rokok}

I Made Adi Satria Darma1*, Wayan Aryadana², I Nyoman Wiryawan², I Gede Raka Widiana ${ }^{3}$, I Gusti Nyoman Kamasan Arijana ${ }^{4}$, Made Satria Yudha Dewangga ${ }^{2}$

\section{ABSTRACT}

Introduction: Sambiloto (Andrographis paniculata) is a plant that spread almost throughout the Indonesian archipelago and has been used for a long time as traditional medicine. Several previous literatures reported that sambiloto has anti-inflammatory and antioxidant effects, so its use is useful in cardiovascular disease, especially in reducing the process of atherosclerosis. The purpose of this study was to determine the effect of giving sambiloto extract on markers of inflammation and atherosclerosis in the form of VCAM- 1 expression and IMT in mice exposed to cigarette smoke.

Methods: This study used an experimental analytical method with a post-test-only group design. Using 32 healthy adult male mice weighing 20-30 grams were divided into four treatment groups, namely: control group (P0) only given exposure to cigarette smoke and treatment group 1 (P1), 2 (P2), and 3 (P3) given exposure cigarettes and sambiloto extract with doses of 18,29 , and $40 \mathrm{mg} / \mathrm{kg} /$ day. Exposure is given for 60 days, then the VCAM-1 expression and IMT in the aortic arch were examined histologically.

Results: There were significant differences in VCAM-1 expression and IMT between the control group and all treatment groups. There was a significant decrease in VCAM-1 expression between $\mathrm{P} 1$ and $\mathrm{P} 2$ and $\mathrm{P} 2$ and $\mathrm{P} 3$. There was a significant decrease in IMT between $P 1$ and $\mathrm{P} 2$ and $\mathrm{P} 2$ and $\mathrm{P} 3$.

Conclusion: Sambiloto extract has effect in decreasing VCAM-1 expression and IMT. That effect strengthens with increasing dose. The maximum effect is obtained with the use of a dose of $40 \mathrm{mg} / \mathrm{kg} /$ day.

Keywords: Andrographis paniculata, VCAM-1, IMT, Atherosclerosis.

Cite This Article: Darma, I.M.A.S., Aryadana, W., Wiryawan, I.N., Widiana, I.G.R., Arijana, I.G.N.K., Dewangga, M.S.Y. 2021. Efek ekstrak sambiloto (Andrographis paniculata) terhadap ekspresi vascular cell adhesion molecule-1

1PPDS-1 IImu Penyakit Jantung dan Pembuluh Darah Fakultas Kedokteran, Universitas Udayana, RSUP Sanglah Denpasar, Bali, Indonesia;

${ }^{2}$ Departemen/KSM IImu Penyakit Jantung dan Pembuluh Darah Fakultas Kedokteran, Universitas Udayana, RSUP Sanglah Denpasar, Bali, Indonesia; ${ }^{3}$ Departemen/KSM IImu Penyakit Dalam Fakultas Kedokteran, Universitas Udayana, RSUP Sanglah Denpasar, Bali, Indonesia;

${ }^{4}$ Departemen/KSM Histologi Fakultas Kedokteran, Universitas Udayana, Denpasar, Bali-Indonesia;

\footnotetext{
*Korespondensi:

I Made Adi Satria Darma;

PPDS-1 IImu Penyakit Jantung dan Pembuluh

Darah Fakultas Kedokteran, Universitas Udayana, RSUP Sanglah Denpasar, Bali, Indonesia; imadeadisatriadarma@gmail.com
}

(VCAM-1) dan intimal media thickness (IMT) pada mencit yang terpapar asap rokok. Intisari Sains Medis 12(3): 828834. D0I: 10.15562/ism.v12i3.1175

\title{
ABSTRAK
}

Latar Belakang: Sambiloto (Andrographis paniculata) merupakan tanaman yang tersebar hampir di seluruh nusantara dan telah digunakan sejak lama oleh masyarakat Indonesia sebagai obat tradisional. Dari beberapa literatur sebelumnya melaporkan sambiloto memiliki efek antiinflamasi dan antioksidan sehingga bermaafaat dalam bidang penyakit kardiovaskular terutama mengurangi proses aterosklerosis. Tujuan dari penelitian ini untuk mengetahui efek pemberian ekstrak sambiloto terhadap petanda inflamasi dan atherosklerosis berupa ekspresi VCAM-1 dan IMT pada mencit yang terpapar asap rokok.

Metode: Penelitian ini menggunakan metode analitik eksperimental dengan rancangan post test only group design. Menggunakan 32 ekor mencit jantan dewasa kondisi sehat dengan berat 20-30 gram dibagi menjadi empat kelompok perlakuan yaitu kelompok kontrol (PO) hanya diberikan paparan asap rokok dan kelompok perlakuan 1 (P1), 2 (P2), dan 3 (P3) diberikan paparan rokok sigaret dan ekstrak sambiloto dengan dosis 18 , 29, dan $40 \mathrm{mg} / \mathrm{kg} /$ hari. Paparan diberikan selama 60 hari, kemudian dilakukan pemeriksaan histologi ekspresi VCAM-1 dan IMT pada arkus aorta mencit.

Hasil: Terdapat perbedaan yang bermakna ekspresi VCAM-1 dan IMT antara kelompok kontrol dengan semua kelompok perlakuan. Terdapat penurunan bermakna ekspresi VCAM-1 antara P1 dengan P2 dan $\mathrm{P} 2$ dengan $\mathrm{P} 3$. Terdapat penurunan bermakna tebal IMT antara P1 dengan P2 dan P2 dengan P3.

Simpulan: Ekstrak sambiloto memiliki efek 
menurunkan ekspresi VCAM-1 dan tebal IMT. Efek maksimal diperoleh dengan penggunaan dosis $40 \mathrm{mg} /$ tersebut meningkat dengan peningkatan dosis. Efek $\mathrm{kg} / \mathrm{hari}$.

Kata kunci: Andrographis paniculata, VCAM-1, IMT, Atherosklerosis.

Sitasi Artikel ini: Darma, I.M.A.S., Aryadana, W., Wiryawan, I.N., Widiana, I.G.R., Arijana, I.G.N.K., Dewangga, M.S.Y. 2021. Efek ekstrak sambiloto (Andrographis paniculata) terhadap ekspresi vascular cell adhesion molecule-1 (VCAM-1) dan intimal media thickness (IMT) pada mencit yang terpapar asap rokok. Intisari Sains Medis 12(3): 828834. D0I: 10.15562/ism.v12i3.1175

\section{PENDAHULUAN}

Merokok merupakan faktor resiko utama penyebab penyakit jantung koroner (PJK), orang yang merokok berisiko dua sampai empat kali lebih tinggi terkena PJK dibandingkan bukan perokok. Asap rokok menyebabkan aktivasi leukosit, peningkatan stress oksidatif dan cidera endotel pembuluh darah yang merupakan awal dari proses atherosclerosis pada akhirnya akan berkembang menjadi PJK. ${ }^{1,2}$ Data riskesdas tahun 2013 prevalensi PJK di Indonesia cukup tinggi diperkirakan 883.447 - 2.650 .340 orang dan di Bali sekitar 12.272 - 39.885 orang. ${ }^{3}$

Pada proses atherosklerosis aktivasi leukosit akan menyebabkan aktivasi NF$\kappa \beta$, peningkatan stress oksidatif akan mengaktifkan signal mitogen activated protein kinase (MPAK) dan cidera sel endotel menyebabkan penurunan fungsi antiadhesi mengakibatkan peningkatan ekspresi molekul adhesi pada endotel. VCAM-1 merupakan salah satu molekul adhesi yang diekspresiken oleh sel endotel menyebabkan migrasi leukosit dari permukaan endotel ke dalam intima. Pada tahap selanjutnya akan terbentuk intimal makrofag dan membentuk foam cell, diikuti proses apoptosis makrofag dan proliferasi otot polos sehingga akan merubah arsitektur intima berupa penebalan dari lapisan intima dan media. Penebalan IMT telah divalidasi sebagai salah satu penanda aterosklerosis pada manusia. ${ }^{4,5}$

Sampai saat ini penanganan aterosklerosis terfokus pada terapi farmokologis dengan statins. Statin terbukti efektif dan ditoleransi dengan baik dalam hal pencegahan dan terapi aterosklerosis. Namun penggunaan statin tidak terlepas dari intoleransi obat, $20 \%$ individu dengan indikasi terapi statin tidak mampu mengkonsumsi obat tersebut perharinya karena intoleransi dan 40-75\% pasien menghentikan terapi statin dalam 1-2 tahun inisiasi statin. Intoleransi yang dialami pasien berupa myalgia 3-5\%, myopathy $0.1-0.2 \%$, onset baru diabetes 9-27\%, dan toksisitas hepar $<1 \% .{ }^{6,7}$

Sambiloto merupakan tanaman yang tersebar luas di nusantara mampu menurunkan inflamasi melalui penurunan produksi NF- $\kappa \beta$ dan bersifat antioksidan dengan mencegah produksi radikal bebas dari maupun menekan ekspresi iNOS. ${ }^{8,9}$ Studi sebelumnya melaporkan efek antiaterosklerosis sambiloto dimana dapat menurunkan MCP-1 yang merupakan petanda awal terjadinya aterosklerosis, memperbaiki dislipidemia, menurunkan oxLDL pada mencit. ${ }^{10,11}$

Penelitian ini dilakukan untuk mengetahui efek sambiloto terhadap marker inflamasi berupa ekspresi VCAM1 dan marker aterogenik berupa tebal IMT pada arkus aorta mencit yang diberikan paparan rokok sigaret.

\section{METODE}

Penelitiaan ini dilakukan di Laboratorium Biomedik Terpadu Fakultas Kedokteran Universitas Udayana. Menggunakan metode penelitian analitik eksperimental dengan rancangan post test only control group design yang dilakukan secara kolaboratif. Sampel yang digunakan berupa mencit jantan galur Swiss Webster umur 8-10 minggu dengan berat badan 20-30 gram dan kondisi sehat. Dari perhitungan penentuan besar sampel, mencit yang digunakan sebanyak 32 ekor. Semua sampel yang memenuhi kriteria inklusi dan eksklusi kemudian dibagi secara acak menjadi empat kelompok perlakuan yaitu kelompok kontrol (P0) hanya diberikan paparan asap rokok dan kelompok perlakuan 1 (P1), 2 (P2), dan 3 (P3) diberikan paparan rokok sigaret dan ekstrak sambiloto dengan dosis 18, 29, dan $40 \mathrm{mg} / \mathrm{kg} / \mathrm{hari}$. Mencit dipelihara dalam kendang secara berkelompok, sebanyak 2 ekor mencit per kendang. Mencit yang mati akan diganti dengan mencit baru yang memenuhi kriteria inklusi dan eksklusi. Rokok kretek dengan kandungan nikotin 2,2 $\mathrm{mg}$ dan tar $31 \mathrm{mg}$ digunakan pada penelitian ini. Pemberian asap rokok dilakukan secara ekstraksi asap arus utama sehingga menyebabkan paparan asap rokok secara aktif. Mencit diberikan paparan 2 batang rokok, 2 kali perhari selama 60 menit. Ekstrak sambiloto dibuat dari seluruh bagian tanaman kecuali bagian akar. Ekstrak sambiloto diberikan setiap hari pada mencit melalui sonde. Paparan asap rokok dan ekstrak sambiloto diberikan selama 60 hari, kemudian dilakukan pemeriksaan histologi ekspresi VCAM-1 dan IMT pada arkus aorta mencit pada hari ke 61.

\section{HASIL}

Total sampel yang digunakan pada penelitian ini sebanyak 40 ekor, saat penelitian berlangsung terdapat 8 ekor mencit mati saat penelitian berlangsung, yang terdiri dari 3 ekor pada kelompok P1, 2 ekor pada kelompok P2, dan 3 ekor pada kelompok P3. Di akhir penelitian 32 ekor mencit yang tersisa dilakukan pemeriksaan histologi dan dilakukan analisis data.

Ekspresi VCAM-1 dihitung berdasarkan sel tunika intima yang mengekspresikan VCAM-1. Mencit yang sudah dilakukan euthanasia diambil jaringan aorta ascenden, kemudian dibuat preparat untuk mengevaluasi jumlah VCAM-1 pada tunika intima aorta ascenden. Hasilnya paparan asap rokok meningkatkan ekspresi VCAM-1 pada semua kelompok. Perbandingan ekspresi VCAM-1 pada semua kelompok dapat 


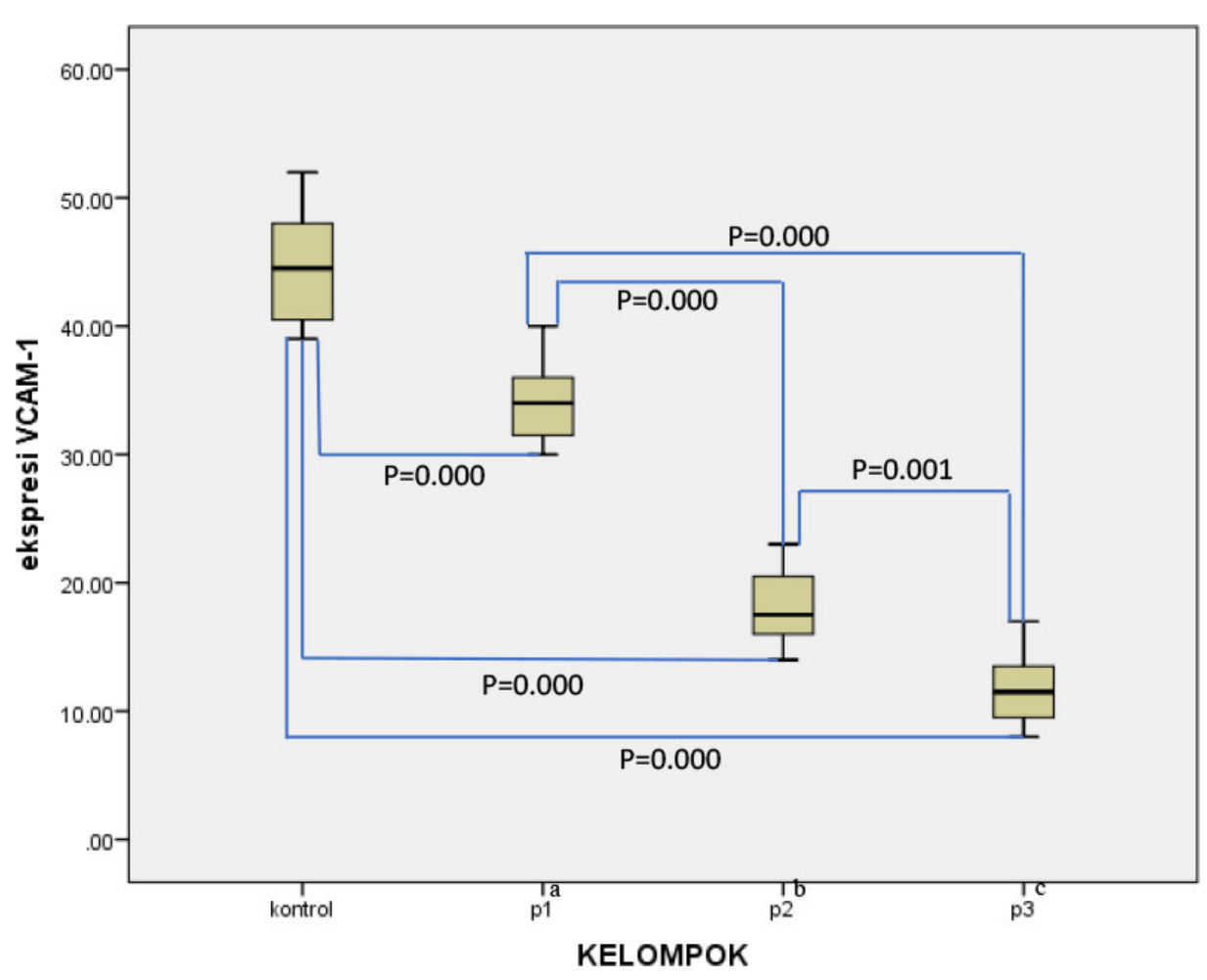

Grafik 1. Grafik Box Plot Perbandingan Rerata Ekspresi VCAM-1 Pada MasingMasing Kelompok. ${ }^{a}$ Kelompok perlakuan 1; ${ }^{b}$ Kelompok perlakuan 2; cKelompok perlakuan 3 .

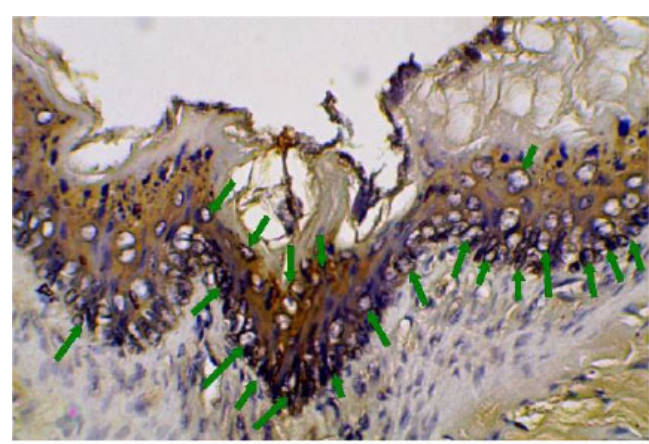

(A)

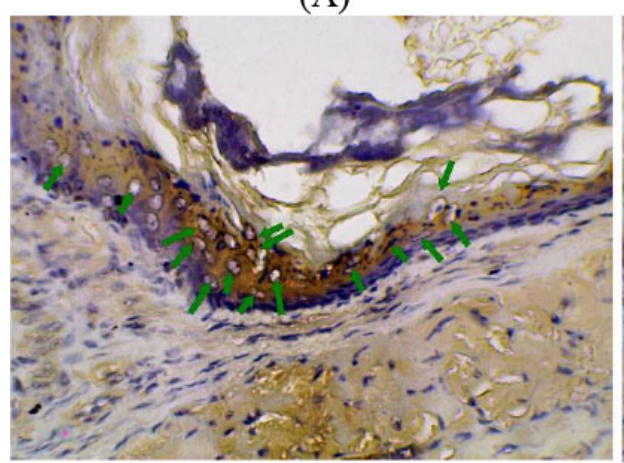

(C)

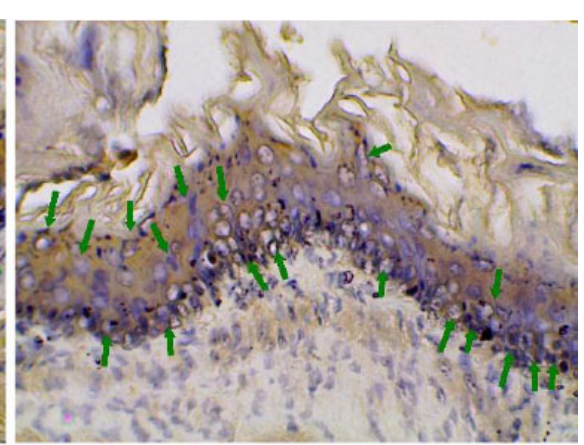

(B)

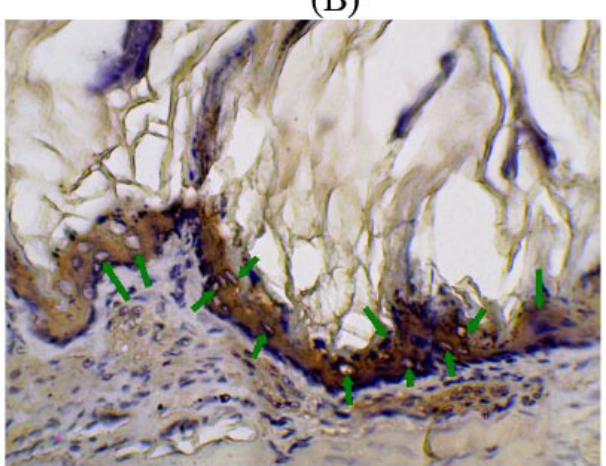

(D)
Gambar 1. Gambaran histologi ekspresi VCAM-1 pada tunika intima arkus aorta. A. Ekspresi VCAM-1 pada kelompok kontrol, B. Ekspresi VCAM-1 pada kelompok perlakuan 1, C. Ekspresi VCAM-1 pada kelompok perlakuan 2, D. Ekspresi VCAM-1 pada kelompok perlakuan 3. dilihat pada grafik 1. Gambaran histologi ekspresi VCAM-1 pada tunika intima arkus aorta dapat dilihat pada gambar 1.

Berdasarkan analisis ditemukan rerata ekspresi VCAM-1 kelompok kontrol lebih tinggi dibandingkan semua kelompok perlakuan (rerata kelompok kontrol 44,63 $\pm 4,63$, rerata kelompok perlakuan satu $34,13 \pm 3,40$, rerata kelompok perlakuan dua $18,13 \pm 3,14$, rerata kelompok perlakuan tiga $11,75 \pm 2,92$ ). Uji normalitas Shapiro wilk didapatkan semua data ekspresi VCAM-1 berdistribusi normal $(\mathrm{P}>0.05)$, dengan varians data homogen $(\mathrm{P}>0.05)$. Analisis dilanjutkan dengan One Way Anova didapatkan perbedaan signifikan antar kelompok $(\mathrm{P}=0.000)$.

Berdasarkan Post hoc analisis menggunakan $L S D$ didapatkan perbedaan signifikan ekspresi VCAM-1 antara kelompok kontrol dengan semua kelompok perlakuan $(\mathrm{P}<0.05)$. Bila ditelaah antara kelompok perlakuan terdapat perbedaan signifikan antara kelompok perlakuan 1 dengan kelompok perlakuan 2 maupun kelompok perlakuan 2 dengan kelompok perlakuan 3 dengan perbedaan masing-masing signifikan $(\mathrm{P}$ $<0.05)$. Dari ketiga kelompok tersebut, dosis pemberian ekstrak sambiloto pada kelompok perlakuan $3(40 \mathrm{mg} / \mathrm{kg} / \mathrm{hari})$ merupakan dosis yang memberikan efek paling maksimal.

IMT diukur setelah dilakukan pembedahan mencit. Preparat difoto mengikuti bentuk pembuluh darah lalu diukur tebal lapisan intima secara histofometri. Tiap foto diukur 3 area kemudian dirata-ratakan. Perbandingan tebal lapisan IMT pada semua kelompok dapat dilihat pada grafik 2. Gambaran histologi IMT pada tunika intima media arkus aorta dapat dilihat pada gambar 2 .

Dari analisis ditemukan tebal lapisan intima pada kelompok kontrol lebih besar dibandingkan semua kelompok perlakuan (rerata kelompok kontrol 23,75 $\pm 3,95$, rerata kelompok perlakuan satu 19,98 $\pm 2,57$, rerata kelompok perlakuan dua $16,46 \pm 3,33$, rerata kelompok perlakuan tiga 13,08 $\pm 2,60$ ). Uji normalitas Shapiro wilk didapatkan semua data ketebalan lapisan IMT berdistribusi normal $(\mathrm{P}>$ $0.05)$ dengan varians data yang homogen $(\mathrm{P}>0.05)$. Analisis dilanjutkan dengan One Way Anova didapatkan perbedaan 


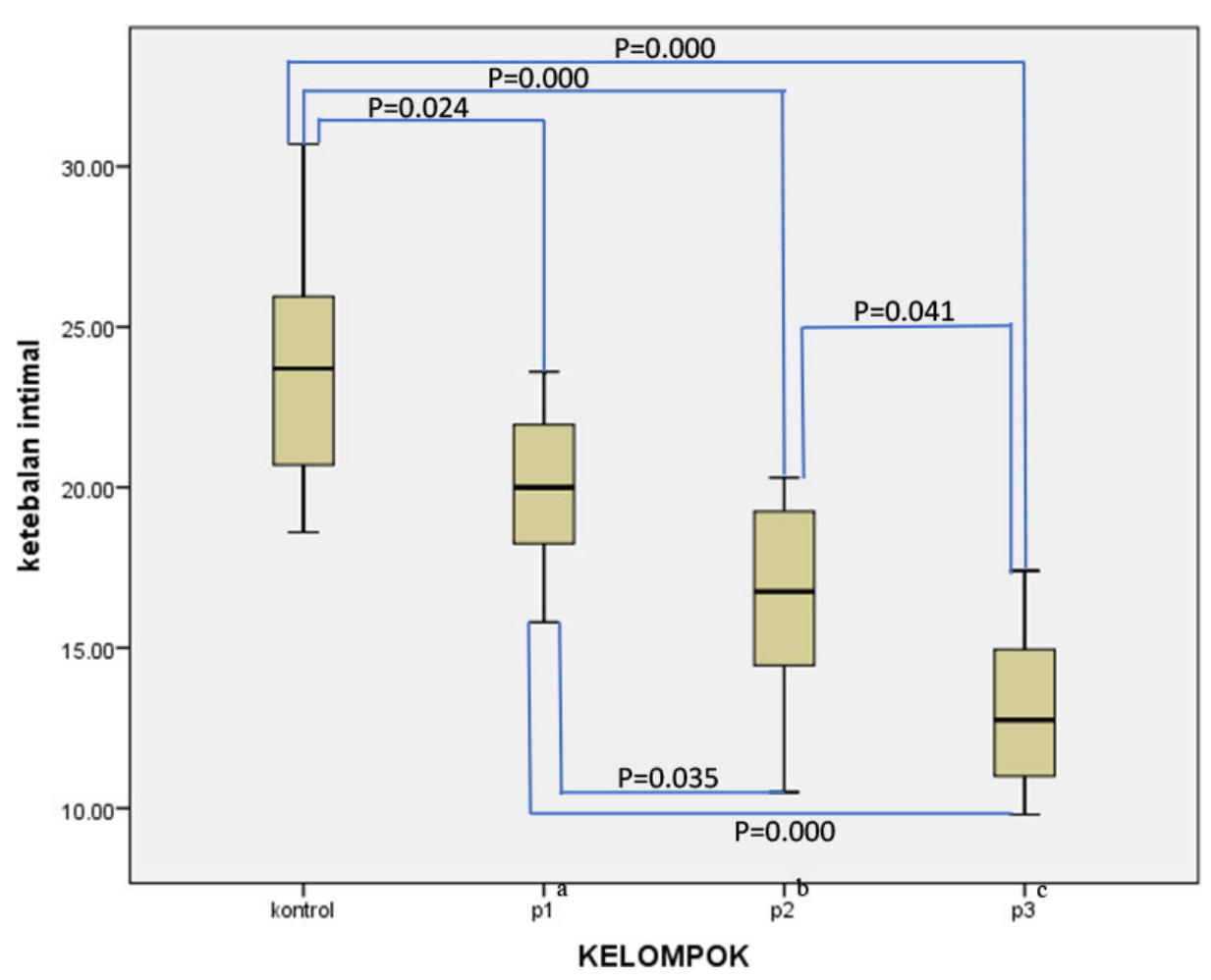

Grafik 2. Grafik Box Plot Perbandingan Tebal lapisan Intima Pada Masing-Masing Kelompok. ${ }^{a}$ Kelompok perlakuan 1; ${ }^{b}$ Kelompok perlakuan 2; ${ }^{\mathrm{C}}$ Kelompok perlakuan 3.

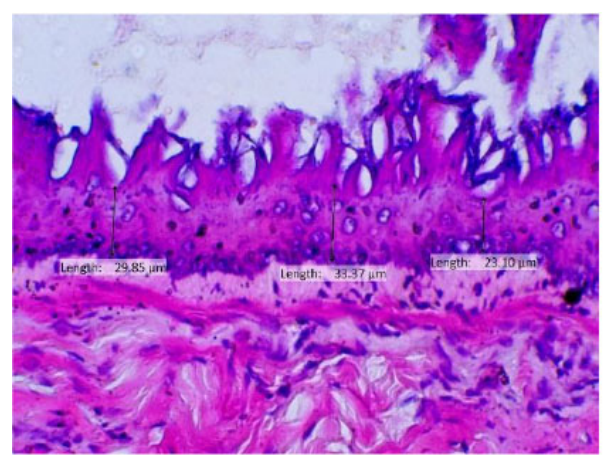

(A)

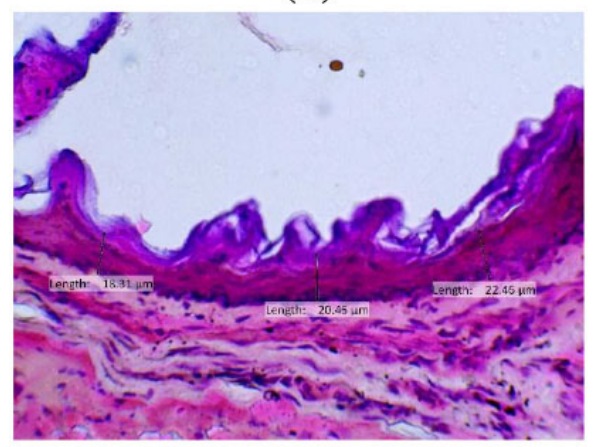

(C)

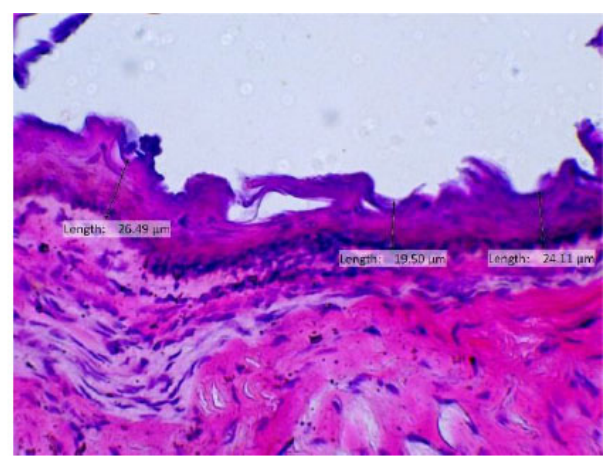

(B)

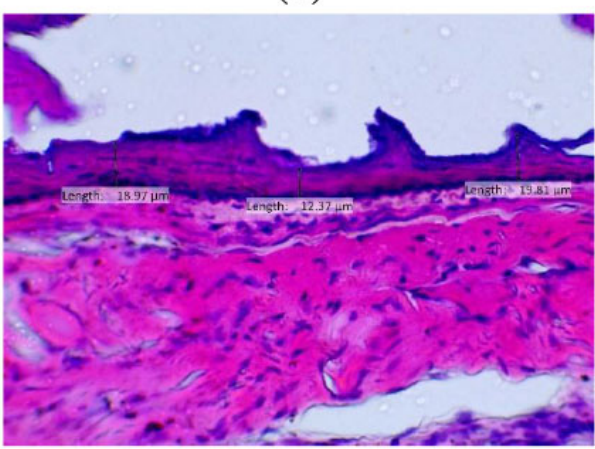

(D)
Gambar 2. Gambaran histologi ketebalan IMT pada tunika intima arkus aorta. A. Ketebalan IMT pada kelompok kontrol, B. Ketebalan IMT pada kelompok perlakuan 1, C. Ketebalan IMT pada kelompok perlakuan 2, D. Ketebalan IMT pada kelompok perlakuan 3. signifikan antar kelompok $(\mathrm{P}=0.001)$.

Berdasarkan Post hoc analisis menggunakan LSD didapatkan perbedaan signifikan ketebalan IMT antara kelompok kontrol dengan semua kelompok perlakuan $(\mathrm{P}<0.05)$. Bila ditelaah antara kelompok perlakuan terdapat perbedaan signifikan antara kelompok perlakuan 1 dengan kelompok perlakuan 2 maupun kelompok perlakuan 2 dengan kelompok perlakuan 3 dengan perbedaan masing-masing signifikan ( $P$ $<0.05$ ). Dari ketiga kelompok tersebut, dosis pemberian ekstrak sambiloto pada kelompok perlakuan 3 (40 mg / kg BB) merupakan dosis yang memberikan efek paling maksimal.

\section{PEMBAHASAN}

\section{Ekstrak Sambiloto Dan Ekspresi VCAM-1}

Pada tahap awal terjadinya atherosklerosis akan terjadi peningkatan ekspresi VCAM1 pada endotel pembuluh darah. VCAM1 pada endotel memfasilitasi migrasi monosit menuju jaringan arteri yang merupakan respon terhadap sitokin proinflamsi lokal. ${ }^{2,12}$ Saat terjadi inflamasi ekspresi VCAM-1 yang diinduksi pada sel endotel dipengaruhi oleh sitokin dan shear stress. Perkembangan plak aterosklerosis lebih lanjut bergantung pada keseimbangan antara mediator proinflamasi dan antiinflamasi yang meregulasi respon inflamasi pada plak yang mempengaruhi stabilitas plak dan kecendrungan formasi thrombus melalui modulasi apoptosis, produksi kolagen dan perubahan sel otot polos vaskuler. ${ }^{13}$

Paparan asap rokok terbukti meningkatkan ekspresi VCAM-1. Sesuai dengan penelitian sebelumnya oleh Yokoyama dkk, dimana pemberian paparan asap rokok sigaret dosis tinggi 120 menit / hari selama 5 hari seminggu selama 2 bulan pada mencit ApoE Knock Out dapat meningkatkan marker atherosklerosis (VCAM-1, ICAM-1, MCP-1, p22phox dan gp91phox) secara signifikan pada aorta ascenden. ${ }^{14}$ Tidak hanya VCAM-1 marker atherogenik lainnya seperti mRNA-ObR juga menunjukkan peningkatan, seperti yang ditunjukkan penelitian sebelumnya yang juga dilakukan di Laboratorium Biomedik Terpadu Fakultas Kedokteran Universitas Udayana dan Laboratorium 
FMIPA Universitas Udayana oleh Dian, dilaporkan bahwa pemberian paparan asap rokok sigaret 120 menit / hari selama 60 hari menunjukkan peningkatan marker atherogenik (mRNA-ObR) secara signifikan dibandingkan kelompok kontrol pada mencit BALB/c. ${ }^{15}$

Pada penelitian ini pemberian ekstrak sambiloto terbukti menurunkan ekspresi VCAM-1, dimana perbedaan efek sudah mulai muncul pada kelompok perlakukan 1 dengan dosis $18 \mathrm{mg} / \mathrm{kg}$ BB. Dengan kecenderungan efeknya meningkat dengan peningkatan dosis pemberian, dimana dosis optimal terdapat pada kelompok perlakuan 3 dengan dosis pemberian ekstrak sambiloto $40 \mathrm{mg} / \mathrm{kg}$ BB. Sampai dengan saat penilitian ini berlangsung, belum terdapat data penilitian sebelumnya yang meneliti efek pemberian ekstrak sambiloto terhadap peningkatan ekspresi VCAM-1. Namun pada penelitian yang dilakukan oleh Hamidy dkk tahun 2019, pemberian andrographolide dengan dosis $40 \mathrm{mg} / \mathrm{kg}$ BB mampu menurunkan ekspresi MCP-1 secara signifikan pada stadium awal atherosklerosis. ${ }^{10}$

Mekanisme ekstrak sambiloto dalam menurunkan ekspresi VCAM-1 melalui penghambatan aktivasi NF- $\kappa \beta$ dan melalui mekanisme antioksidan. Penelitian sebelumnya menunjukkan bahwa andrographolide memiliki efek anti inflamasi melalui inaktivasi NF$\kappa \beta$. Dimana NF- $\kappa \beta$ merupakan faktor transkripsi yang memiliki peran penting dalam mengatur berbagai sitokin dan kemokin yang terlibat dalam proses inflamasi. Penghambatan aktivitas NF- $\kappa \beta$ oleh andrographolide terjadi melalui defosforilasi dari p65 dengan mengaktifkan PP2A9. Defosforilasi p65 oleh andrographolide menghasilkan penurunan translokasi NF- $\kappa \beta$ ke dalam nukleus dan mengurangi pengikatan NF$\mathrm{kB}$ sehingga mengurangi proses terjadinya inflamasi. ${ }^{16}$

Pada penelitian sebelumnya mengenai kerusakan oksidatif edotelium dengan $400 \mu \mathrm{M} \mathrm{H} 2 \mathrm{O} 2$ pada sel endotel dilaporkan terjadi peningkatan ROS dan menginduksi peningkatan ekspresi VCAM-1. Saat aktivasi sinyal VCAM1, oksidasi $1 \mu \mathrm{M} \mathrm{H} 2 \mathrm{O} 2$ prodomain dari matrix metalloproteinases (MMPs) menyebabkan celah autocatalytic dari prodomain dan aktivasi MMPs. $1 \mu \mathrm{M}$ $\mathrm{H} 2 \mathrm{O} 2$ juga akan mengalami difusi pada membrane sel dengan kecepatan 100 $\mu \mathrm{m} / \mathrm{s}$. ROS intraseluler akan mengaktivasi sel endotel p38MAPK untuk regulasi formasi gap pada sel endotel. $1 \mu \mathrm{M} \mathrm{H} 2 \mathrm{O} 2$ juga secara langsung mengalami oksidasi dan secara transien mengaktivasi protein kinase $\mathrm{Ca}(\mathrm{PKC} a)$ intraseluler. Aktivasi PKCa menginduksi fosforilasi dan aktivasi protein tyrosine phosphatase $1 \mathrm{~B}$ (PTP1B). Menariknya PTP1B memiliki cysteine yang dapat teroksidasi pada domain catalytic dan tidak teroksidasi saat aktivasi sinyal VCAM-1 pada sel endotel mengindikasikan target spesifik untuk oksidasi dengan ROS konsentrasi rendah yang terbentuk saat aktivasi sinyal VCAM-1. ${ }^{17}$ Pemberian ekstrak sambiloto (Andrographis paniculata) pada hewan coba memiliki efek potensial untuk menjaga keseimbangan antara antioksidan seperti nitric oxide, cyclic guanosine monophosphate maupun superoksida dismutase dengan prooksidan seperti endhotelin pada sel endotel. ${ }^{9}$

\section{Ekstrak Sambiloto dan Tebal IMT}

Pada penelitian ini pemberian paparan asap rokok selama 60 hari menyebabkan peningkatan ketebalan lapisan IMT arkus aorta pada semua kelompok. Hasil ini serupa dengan penelitian oleh Zhang dkk tahun 2015 dimana terjadi peningkatan ketebalan IMT pada arkus aorta mencit LDL $\mathrm{R}^{-/}$dibandingkan kontrol yang berusia 24 miggu. ${ }^{18}$

Mekanisme terjadinya peningkatan lapisan IMT pada mencit yang terpapar asap rokok melalui aktivasi sinyal jalur MAPK. Penenlitian invitro oleh Nakamura tahun 2018, dilaporkan bahwa pemberian paparan nikotin selama 48 jam pada sel otot polos primer aorta manusia meyebabkan aktivasi sinyal P38 MAPK menyebabkan perubahan sel otot polos vaskular menjadi syntetic-like phenotype disertai migrasi menuju plak atheroma pada tunika intima sehingga terjadi perubahan arsitektur pada IMT, berupa penebalan lapisan IMT. ${ }^{19}$ Selain itu paparan nikotin juga menyebabkan aktivasi sinyal P38 MAPK juga menyebabkan peningkatan ekspresi molekul adhesi VCAM-1 pada sel endotel. ${ }^{4}$

Pada penelitian ini pemberian ekstrak sambiloto terbukti mengurangi penebalan lapisan IMT, dimana perbedaan efek sudah mulai muncul pada kelompok perlakuan 1 dengan dosis pemberian 18 $\mathrm{mg} / \mathrm{kg}$ BB. Dengan kecendrungan efeknya meningkat dengan peningkatan dosis pemberian, dimana dosis optimal terdapat pada kelompok perlakuan 3 dengan dosis pemberian ekstrak sambiloto $40 \mathrm{mg} / \mathrm{kg}$ BB.

Mekanisme ekstrak sambiloto mencegah penebalan IMT melalui penghambatan kaskade P38 MAPK. Andrographolide mempunyai efek antiplatelet melalui aktivitasi jalur eNOsNO/cyclic GMP dan menghambat kaskade PLCg2-PKC dan PI3 kinase/Akt-MAPK (contoh p38 MAPK). Andrographolide mungkin meningkatkan cyclic $G M P / P K G$ dan menghambat kaskade p38MAPK/ HO-NF-kB-ERK2 pada platelet. Andrographolide memiliki potensi meghmbat proses inflamasi dan proses tromboembolik. ${ }^{20}$

\section{Pemilihan Mencit Dan Ekstrapolasi Studi Pada Manusia}

Peggunaan hewan coba dalam penelitian penyakit kardiovaskular dapat mempermudah mempelajari patofisiologi penyakit serta strategi dan komplikasi terapeutik sebelum nantinya diaplikasikan ke manusia. Mencit merupakan model binatang yang paling banyak digunakan dalam riset-riset yang berkaitan dengan aterosklerosis. Genom pada mencit memiliki banyak kesamaan, dengan kemiripan hampir 95\% pada berbagai gen protein pengkode pada manusia. Studi GWAS (Genome Wide Association Studies) telah mengidentifikasi lokus - lokus dan gen-gen yang berkorelasi kuat terhadap timbulnya penyakit jantung koroner pada manusia. Adanya studi ini memberikan kesempatan untuk menguji relevansi studi yang menggunakan mencit dengan proses timbulnya penyakit jantung koroner pada manusia. Hasilnya adalah didapatkan lebih dari 50\% jalur bersifat identik dan bersifat tumpang tindih dengan jalur atherosklerois pada manusia. ${ }^{21}$

Mencit juga memiliki sistem kardiovaskular atau pembuluh darah yang mirip dengan manusia. Organ utama adalah jantung beserta pembuluh darah seperti aorta, arteri, dan vena. Proses aterosklerosis pada mencit terjadi mulai 
dari sinus aorta sampai arteri iliaka. Pada penilitian ini pengambilan sampel jaringan dilakukan pada arkus aorta mayoritas dari karena dari beberapa penelitin sebelumnya proses aterosklerosis sering terjadi pada area tersebut dan secara teknis lebih mudah untuk dilakukan. Pertimbangan lain karena terdapat kesulitan untuk mengambil jaringan arteri koroner, oleh karena ukurannya yang sangat kecil.,,22

\section{Penyebab Kematian pada Mencit Penelitian}

Terdapat 8 ekor mencit yang mati selama penelitian berlangsung, terdiri dari 3 ekor pada kelompok perlakuan 1, 2 ekor pada kelompok perlakuan 2 dan 3 ekor pada kelompok perlakuan 3. Mencit yang mati pada kelompok 1, 2, dan 3 terjadi setelah pemberian ektrak sambiloto selama $1-2$ minggu. Sebelum mati mencit mengalami gejala muntah-muntah dan lemas. Menurut literatur penyebab kematian pada penelitian dengan hewan coba mencit dapat disebabkan karena kematian jantung mendadak (aritmia), intoksikasi, anoksia, infeksi fulminan, anemia, syok anafilaksis dan syok traumatic. ${ }^{23}$ Penyebab kematian mencit pada penelitian ini dicurigai karena intoksikasi atau syok anafilaksis. Meskipun pada penelitian uji toksisitas akut dan subakut andrographolide pada mencit dengan pemberian secara oral, dilaporkan bahwa andrographolide masih aman diberikan sampai dengan dosis 5 $\mathrm{g} / \mathrm{kg}$ pada kelompok uji toksisitas akut dan dosis $500 \mathrm{mg} / \mathrm{kg}$ selama 21 hari pada kelompok uji toksisitas subakut. ${ }^{24}$ Untuk mengetahui secara pasti penyebab kematian mencit penelitian ini dapat dilakukan uji toksisitas ektrak sambiloto akut dan subakut pada penelitian selanjutnya.

\section{Keterbatasan Penelitian}

Terdapat beberapa sampel penelitian muntah-muntah setelah diberikan ekstrak sambiloto sehingga dosis yang masuk ke tubuh mencit menjadi tidak akurat. Belum dilakukan uji toksisitas pemberian ekstrak sambiloto pada penelitian ini, untuk mengetahui keamanan penggunaan ekstrak ini.

\section{SIMPULAN}

Ekstrak sambiloto memiliki efek menurunkan ekspresi VCAM-1 dan tebal IMT. Terdapat perbedaan ekspresi VCAM-1 antara kelompok kontrol dengan semua kelompok perlakuan dan terdapat perbedaan tebal lapisan IMT antara kelompok kontrol dengan semua kelompok perlakuan. Efek tersebut meningkat dengan peningkatan dosis. Terdapat penurunan ekspresi VCAM1 antara kelompok P1 dengan P2 dan kelompok P2 dengan P3. Terdapat penurunan tebal IMT antara kelompok P1 dengan P2 dan kelompok P2 dengan P3 Efek maksimal diperoleh dengan penggunaan dosis $40 \mathrm{mg} / \mathrm{kg} / \mathrm{hari}$.

\section{KONFLIK KEPENTINGAN}

Penulis menyatakan tidak terdapat konflik kepentingan terkait publikasi dari artikel penelitian ini.

\section{PENDANAAN}

Penelitian ini tidak mendapatkan pendanaan dari pemerintah maupun sektor swasta lainnya.

\section{ETIKA DALAM PENELITIAN}

Penelitian ini telah mendapat persetujuan dari Komite Etik Penelitian (KEP) Fakultas Kedokteran Universitas Udayana/Rumah Sakit Umum Pusat Sanglah Denpasar.

\section{KONTRIBUSI PENULIS}

Seluruh penulis telah berkontribusi dalam penulisan artikel penelitia dan setuju terhadap versi akhir dari naskah penelitian untuk dilakukan publikasi.

\section{DAFTAR PUSTAKA}

1. Chambless LE, Folsom AR, Sharrett AR, Sorlie P, Couper D, Szklo M, et al. Coronary heart disease risk prediction in the Atherosclerosis Risk in Communities (ARIC) study. J Clin Epidemiol. 2003;56(9):880-90. Available from: $\quad$ http://dx.doi.org/10.1016/s08954356(03)00055-6

2. Morris PB, Ference BA, Jahangir E, Feldman DN, Ryan JJ, Bahrami H, et al. Cardiovascular Effects of Exposure to Cigarette Smoke and Electronic Cigarettes. J Am Coll Cardiol. 2015;66(12):1378-91. Available from: http:// dx.doi.org/10.1016/j.jacc.2015.07.037
3. Badan Penelitian dan Pengembangan Kesehatan Kementrian Kesehatan RI. Penyajian PokokPokok Kesahatan Dasar 2013. www.litbang. depkes.go.id

4. Yin HS, Li YJ, Jiang ZA, Liu SY, Guo BY, Wang T. Nicotine-induced ICAM-1 and VCAM1 expression in mouse cardiac vascular endothelial cell via p38 MAPK signaling pathway. Anal Quant Cytopathol Histpathol. 2014;36(5):258-62.

5. Gan L, Grönros J, Hägg U, Wikström J, Theodoropoulos C, Friberg P, et al. Noninvasive real-time imaging of atherosclerosis in mice using ultrasound biomicroscopy. Atherosclerosis. 2007;190(2):313-20. Available from: http://dx.doi.org/10.1016/j. atherosclerosis.2006.03.035

6. Erwinanto SA. Panduan tatalaksana dislipidemia. Perhimpunan Dokter Spesialis Kardiovaskular Indonesia. Jurnal Kardiologi Indonesia. 2017;14-53

7. Toth PP, Patti AM, Giglio RV, Nikolic D, Castellino G, Rizzo M, et al. Management of Statin Intolerance in 2018: Still More Questions Than Answers. Am J Cardiovasc Drugs. 2018;18(3):157-73. Available from: https:// pubmed.ncbi.nlm.nih.gov/29318532

8. de Winther MP, Kanters E, Kraal G, Hofker MH. Nuclear factor kappaB signaling in atherogenesis. Arterioscler Thromb Vasc Biol. 2005;25(5):904-14. doi: 10.1161/01. ATV.0000160340.72641.87.

9. Wu T, Peng Y, Yan S, Li N, Chen Y, Lan T. Andrographolide Ameliorates Atherosclerosis by Suppressing Pro-Inflammation and ROS Generation-Mediated Foam Cell Formation. Inflammation. 2018;41(5):1681-9. Available from: http://dx.doi.org/10.1007/s10753-0180812-9

10. H Hamidy MY, Oenzil F, Yanwirasti Y, Aldi Y. Effect of Andrographolide on Monocyte Chemoattractant Protein-1 Expression at the Initiation Stage of Atherosclerosisin Atherogenic Diet-Fed Rats. 2019;12(3):1167-73. Available from: https://doi.org/10.13005\%2Fbpj\%2F1745

11. Warditiani NK, Susanti NMP, Arisanti CIS, Putri NPRD, Wirasuta IMAG. Antidyslipidemia And Antioxidant Activity Of Andrographolide Compound From Sambiloto (Andrographis Paniculata) Herb. Int $J$ Pharm Pharm Sci. 2017;9(7):59. Available from: http://dx.doi. org/10.22159/ijpps.2017v9i7.18109

12. Monaco C, Caligiuri G. The ESC Textbook of Vascular Biology [Internet]. Oxford Medicine Online. Oxford University Press; 2017. Available from: http://dx.doi.org/10.1093/ med/9780198755777.001.0001

13. Čejková S, Králová Lesná I, Poledne R. Monocyte adhesion to the endothelium is an initial stage of atherosclerosis development. Cor Vasa. 2016;58(4):e419-25. Available from: http://dx.doi.org/10.1016/j.crvasa.2015.08.002

14. Yokoyama Y, Mise N, Suzuki Y, Tada-Oikawa S, Izuoka K, Zhang L, et al. MicroRNAs as Potential Mediators for Cigarette Smoking Induced Atherosclerosis. Int J Mol Sci. 2018;19(4):1097. Available from: https://pubmed.ncbi.nlm.nih. gov/29642385 
15. Dian, AP. Pengaruh Paparan Asap Rokok Elektrik dan Asap Rokok Konvensional Terhadap Peningkatan Penanda Aterogenik: Reseptor Leptin (Mrna-ObR) dan Kalsifikasi Aorta Pada Mencit; 2021

16. Hsieh CY, Hsu MJ, Hsiao G, Wang YH, Huang CW, Chen SW. Andrographolide enhances nuclear factor- $\kappa \beta$ subunit p56 ser536 dephosphorylation through activation of protein phosphatase $2 \mathrm{~A}$ in vascular smooth muscle cells. The Journal of Biological Chemistry. 2011;286(8):5942-55. Available from: https:// doi.org/10.1074\%2Fjbc.m110.123968

17. Cook-Mills JM, Marchese ME, Abdala-Valencia $\mathrm{H}$. Vascular cell adhesion molecule-1 expression and signaling during disease: regulation by reactive oxygen species and antioxidants. Antioxid Redox Signal. 2011/05/11. 2011;15(6):1607-38. Available from: https:// pubmed.ncbi.nlm.nih.gov/21050132

18. Zhang X, Ha S, Wei W, Duan S, Shi Y, Yang Y. Noninvasive Imaging of Aortic Atherosclerosis by Ultrasound Biomicroscopy in a Mouse Model. J Ultrasound Med. 2015;34(1):111-6.
Available from: http://dx.doi.org/10.7863/ ultra.34.1.111

19. Nakamura A. Effects of Nicotine Contained in Tobacco Mainstream Smoke on Vascular Smooth Muscle Cells [Internet]. Atherosclerosis-Yesterday, Today and Tomorrow. InTech; 2018. Available from: http:// dx.doi.org/10.5772/intechopen.77010

20. Jayakumar T, Hsieh C-Y, Lee J-J, Sheu J-R. Experimental and Clinical Pharmacology \{ofAndrographis\} paniculataand Its Major Bioactive Phytoconstituent Andrographolide. 2013;2013:1-16. Available from: https://doi. org/10.1155\%2F2013\%2F846740

21. von Scheidt M, Zhao Y, Kurt Z, Pan C, Zeng L, Yang X, et al. Applications and Limitations of Mouse Models for Understanding Human Atherosclerosis. Cell Metab. 2016/12/01. 2017;25(2):248-61. Available from: https:// pubmed.ncbi.nlm.nih.gov/27916529

22. Getz GS, Reardon CA. Animal models of atherosclerosis. Arterioscler Thromb Vasc Biol. 2012/03/01. 2012;32(5):1104-15.
Available from: https://pubmed.ncbi.nlm.nih. gov/22383700

23. Manskikh VN. The Problem of Determination of Cause of Laboratory Animal's Death: A Critical Review of Definitions of "Fatal" and "Incidental" Lession. Biochemistry (Moscow). Original Russian Text. 2014;79(10):1075-80. Available from: https:// doi.org/10.1134\%2Fs0006297914100095

24. Bothiraja C, Pawar AP, Shende VS, Joshi PP. Acute and subacute toxicity study of andrographolide bioactive in rodents: Evidence for the medicinal use as an alternative medicine. Comp Clin Path. 2012;22(6):1123-8. Available from: http://dx.doi.org/10.1007/s00580-0121539-x

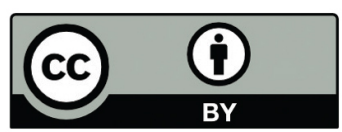

This work is licensed under a Creative Commons Attribution 